\title{
Assessing Public Open Spaces: A Case of City Nagpur, India
}

\author{
Pritam Ahirrao *(D) and Smita Khan \\ Department of Architecture and Planning, Visvesvaraya National Institute of Technology, Nagpur 440010, India; \\ smitakhan@arc.vnit.ac.in \\ * Correspondence: ahirrao.pritam12@gmail.com
}

Citation: Ahirrao, P.; Khan, S. Assessing Public Open Spaces: A Case of City Nagpur, India. Sustainability 2021, 13, 4997. https://doi.org/10.3390/su13094997

Academic Editor: Manuel Duarte Pinheiro

Received: 16 March 2021

Accepted: 24 April 2021

Published: 29 April 2021

Publisher's Note: MDPI stays neutral with regard to jurisdictional claims in published maps and institutional affiliations.

Copyright: (C) 2021 by the authors Licensee MDPI, Basel, Switzerland. This article is an open access article distributed under the terms and conditions of the Creative Commons Attribution (CC BY) license (https:/ / creativecommons.org/licenses/by/ $4.0 /)$.

\begin{abstract}
Major Indian cities have a lower public open space (POS)-capita ratio and do not meet national and international standards. Moreover, factors such as lack of design guidelines for POSs, limited funding, and lack of public participation have affected these limitedly available POSs and made them ineffective and incapable of meeting the contemporary needs of a diverse range of users. Therefore, it is essential to make them not only inclusive, user-friendly, attractive, and efficient, but also socially, economically, and environmentally sustainable in order to serve the various facilities and services at their optimum level. This study includes the assessment of two POSs to identify strengths and deficiencies that affect their character and use. These POSs are public parks, provide free access to users and are located in the city of Nagpur. For assessment, the study proposed the Public Open Space Index (POSI) that combines five aspects: Individual well-being, Inclusiveness, Engagement, Sustainable spaces, and Management.A mixed methods approach was considered for data collection, including a self-administered questionnaire survey and observations.According to the results, POSs have strengths in that they facilitate social cohesion, engagement, and basic facilities. POSs do not encourage equitable access and sustainable practices, which are considered deficiencies.The study helps planners, designers, and parenting authority to develop initiatives to make these limited POSs inclusive, functional, and sustainable.
\end{abstract}

Keywords: user's perception; quality of life; parks; public open space index; sustainability

\section{Introduction}

Public open spaces (POSs) are considered to be recreational areas, where human beings develop social relationships [1]. Here, a lively gathering of people takes place for a variety of purposes and occasions. Due to many benefits, these POSs are considered as one of the most valued and crucial elements in the development of the urban environment. Scholars have argued that high-quality POSs help to enhance the quality of life of their users [2]. In India, major cities are facing a number of challenges due to rapid urbanisation. These challenges include a vast scale of migration, high population density, and increased land prices [3]. Existing and proposed development plans for various major cities have shown that these cities have a lower space-capita ratio and do not meet national and international standards [4-9]. Urban and regional development plan formulation and implementation (URDPFI) and World Health Organisation (WHO) standards have suggested an ideal ratio of 9 Sq.m to 12 Sq.m POS per capita at the city level $[10,11]$. Another observation indicated that the lack of design guidelines for POSs, limited funding, and lack of public participation have affected these limitedly available POSs and have made them ineffective and incapable of meeting the contemporary needs of a wide range of users [3,12]. Therefore, it is essential to make these POSs not only inclusive, user-friendly, attractive, and functional, but also socially, economically, and environmentally sustainable so they can serve the various facilities and services at their optimum level.

Literature shows several studies on POSs have been conducted in India from various perspectives. Studies such as environmental impact on POSs, Chennai [13], analysis of environmental attributes of POSs, Pune [14], urbanisation impact on POSs, Bangalore [15], 
growing and preserving POSs and green cover, Bangalore [16], etc. have been conducted based on environmental, social and planning perspectives. Fewer studies are available that provide insights into the character and use of POSs. Such studies have been conducted in Western countries and must be considered in South Asian countries with a different cultural context. This study fills a current gap. The aim of the study is to identify strengths and deficiencies of POSs that affect their character and use. The study follows the vision of Sustainable Development Goals 11 (SDG 11) of the United Nations that encourages sustainable and inclusive development [17]. For this study, sustainable development is considered as' a development that meets people's current needs without compromising the ability of future generations to meet their own needs. ' In addition, 'promote development to meet people's basic needs while also fostering social and economic growth and mitigating environmental degradation' [18].

The study focuses on two POSs. These POSs are public parks, offer free access to users and are located in the city of Nagpur. For the assessment, the study proposed the Public Open Space Index (POSI) that combines five aspects: Individual well-being, Inclusiveness, Engagement, Sustainable spaces, and Management. The study adopted a mixed approach, including a self-administered questionnaire survey and site observation for data collection. A total of 553 visitors from both POSs participated in the main survey. The study helps planners, designers, and parental authority to develop initiatives to make these limited POSs inclusive, functional, sustainable, and contribute to improving the quality of life of users. Figure 1 shows a schematic representation of the methodology adopted for the study.

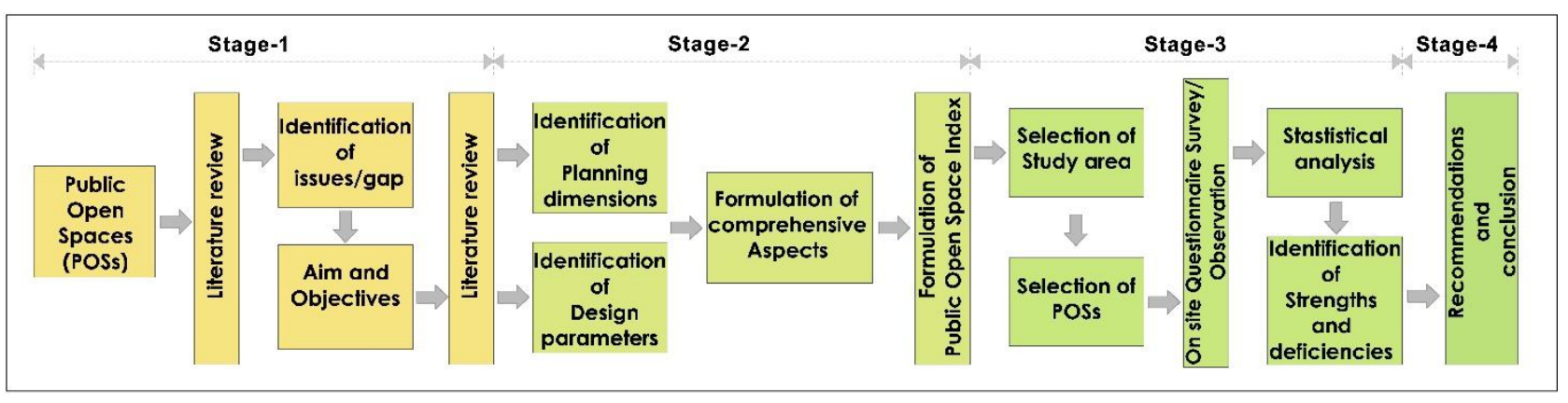

Figure 1. Schematic representation of the methodology adopted for the study.

Facilities, services, and the appearance of POSs provide various benefits to the users $[19,20]$. The aim of the study is to identify the strengths and deficiencies of POSs that would help planners and designers to enhance their character and use. The study considered users' perceptional opinion for assessing the POSs. Perception is defined as an experience caused by the stimulation of sense organs [21]. A user perceives space and expresses an opinion about it [22]. This study assumes the user's opinion of visiting or using space is based on the perception he/she has gained through the available facilities, services, and aesthetic appearance of that POS. Perception is a latent and subjective variable that could be beyond the control of planners and designers. However, planners and designers can change the facilities, services, and aesthetic appearance of the space [23]. To prove the assumption, the study demonstrates a hypothesis that user's perception has a close relationship with the space facilities, services, and aesthetics.

\section{Literature Review}

\subsection{Public Open Space (POS)}

POSs are social spaces generally open and accessible to all people [24]. Scholars explained POS as "an outdoor area which is open to freely chosen and spontaneous activities, movement, or visual exploration" [25]. POSs help people to share their culture, ideas, and emotions that represent society [24,25]. POSs encourage social interaction, gathering, common activities, and programmes that build a "sense of community" among people. 
Scholars suggested some noteworthy characteristics of good POSs, such as connecting people to nature [26], encouraging active and passive activities [25], granting freedom in action and access [24,27], promoting leisure and recreational facilities, and providing a stage for public art and performance [28].

\subsection{Public Open Space Index (POSI)}

The study considered urban planning and design literature for the formulation of the Public Open Space Index (POSI).The field of urban planning emphasises the importance of social, economic, and environmental dimensions in order to achieve sophisticated and sustainable development $[29,30]$. Literature argued that these three dimensions are essential for addressing the city's challenges and promoting inclusive development [31-34]. Urban design is a branch of architecture that aims to make spaces usable, visually pleasing, and convenient. It focuses on space layout, appearance, user activity, human scale, and user-space attachment $[35,36]$. In order to establish a theoretical framework, the study considered three design parameters, such as functional, aesthetic, and user-centric approach [37-40]. The study has established aspects that promote planning dimensions as well as design parameters. The aspects are Individual well-being, Inclusiveness, Engagement, Space sustainability, and Management. These aspects aid researcher in the development of the Public Open Space Index (POSI). The assessment was carried out on the site scale.

The first aspect, Individual well-being, relates to functional, aesthetic, and user-centric parameters and social dimension. Well-being is defined as a state of happiness, health, relaxation, and a comfortable lifestyle [41,42]. In terms of POS, a human desire causes people to visit POSs that provide them with physical and psychological comfort. Here, comfort refers to a state where space promotes physical and psychological relief and satisfies human needs through the provision of convenient physical conditions, facilities, and aesthetical features $[43,44]$. A well-defined and visible entrance gives comfort to users and allows them to enter the POS. Wide, single-level walkways within POS improve usability and provide physical comfort not only to joggers but also to senior citizens who prefer walking [45-47]. Furthermore, the climate responsive design of POS also improves physical comfort $[48,49]$. The open and shaded area, semi-covered seating, and shelter facilities allow users to use the space during different seasons. In terms of psychological comfort, the availability of focal points and vistas create visually appealing and pleasing views for users $[43,50,51]$. These elements create a perceivable and positive image of the POS between users [52,53]. Additionally, POS that receives less outside noise improves psychological comfort.

The second aspect, Inclusiveness, is linked with the functional, user-centric parameters and social dimension. Inclusive spaces promote a democratic public realm by facilitating equitable gathering and discussion. Here, users connect with the community and gain a sense of belonging [54]. The literature emphasises equitable access, social cohesion, and users' freedom to explain inclusiveness. Equitable access encourages all users to have access to POS $[55,56]$. Social cohesion involves interpersonal dynamics and a sense of interpersonal relationship between individuals [57]. Social cohesion in POSs could be achieved by giving people the opportunity to participate in events and programmes, to engage in positive conversation, and to share their experiences [58]. Regarding users freedom, scholars argued that POS should promote an open and unrestricted environment in which users feel free to act $[43,44]$. Space management authority must protect the privacy of users. The authority should neither retain control of the entrance nor impose any restrictions on the activities, behaviour, and roaming of users [43,44].

Engagement, the third aspect, promotes functional, user-centric parameters, and social dimension. The aspect focuses on users' effective involvement in activities. The literature described two approaches to achieving effective engagement in POSs. The first is "engagement with space", and the second is "engagement with community" [24,43,44,59]. If POS accommodates activities according to users' needs, then users effectively engage 
with space $[60,61]$. Factors such as space flexibility, layout, and design also contribute to effective engagement. Here, flexibility means the versatility of space to adapt changes to users' needs $[24,38]$. Scholars argued that active and passive activities help users to engage with a space $[24,25]$. Other activities, such as necessary, social, and optional activities, also contribute to improving the experience of space [62]. Furthermore, lively space edges those promote activities such as food, soft drinks, reading, shopping, and entertainment allow users to stay within space for an extended period of time [39,43]. The second method, "engagement with community", emerges when POS provides the user with an opportunity to interact with other familiar and unknown users $[54,63,64]$. It helps people to trust one another, to feel proud, and to respond to their communal obligations.

The fourth aspect, 'Sustainable spaces', promotes functional, user-centric parameters as well as economic and environmental dimensions. The aspect focuses on achieving economic and environmental sustainability $[18,31,65]$. Scholars argued economic sustainability could be recognised by promoting adequate employment, business, livelihood opportunities, and reducing the cost of living and health [66]. The ability of POS to promote nearby businesses such as shopping, hotels, street food, and other commercial activities not only helps the neighbourhood and city grow economically, but also improves the quality of life for those who depend on these businesses. In addition, POS helps reduce the cost of living by offering access to community services, amenities, and leisure facilities [66]. Environmental sustainability emphasises the use of responsible practices for energy, water, and soil conservation [31,32,67]. Such practices include use of renewable energy resources, rainwater harvesting, waste management, energy and water-efficient irrigation systems, and intelligent artificial lighting in the POS [68]. Environmental sustainability could also be achieved by promoting sustainable landscape practices, such as the use of native species, xeriscaping, and the preservation of natural topography $[69,70]$.

The fifth aspect, Management, is linked with functional, user-centric parameters as well as social and environmental dimensions. People prefer to visit spaces where they find a safe environment, especially women, children, and senior citizens [71,72].Scholars suggested some techniques for achieving safety within POSs. Shaftoe [39] and Oc and Tiesdel [72] recommended a Panoptic approach, which includes the presence of security guards, and a CCTV system in POSs. Moreover, Marcus and Francis [2], Lang and Marshall [73] suggested passive control, including the display of written or symbolic instructions to prevent unwanted activities. Shaftoe [39] and Jacobs [52] recommended "eyes on space" or natural surveillance by space users and adjacent neighbourhood dwellers. Users' behaviour and responsibility are also important factors in maintaining a safe environment within the POS. Carr et al [24] suggested "responsible freedom", which means a person can use POS as per his/her wishes, but with the recognition that POS is a public and shared space. Carmona [74] and PPS [44] explained that users should respect POS as their national property, avoid activities like vandalism and littering, and maintain peace within the space. Carmona [74] described the space management authorities should respect the rights of users. These rights include privacy, equitable behaviour and handling for all users, allowing photography, discussion, rest, and freedom of movement. Basic facilities should be provided, such as drinking water, clean washrooms, and first aid. Figure 2 shows the analytical framework considered for the study. 


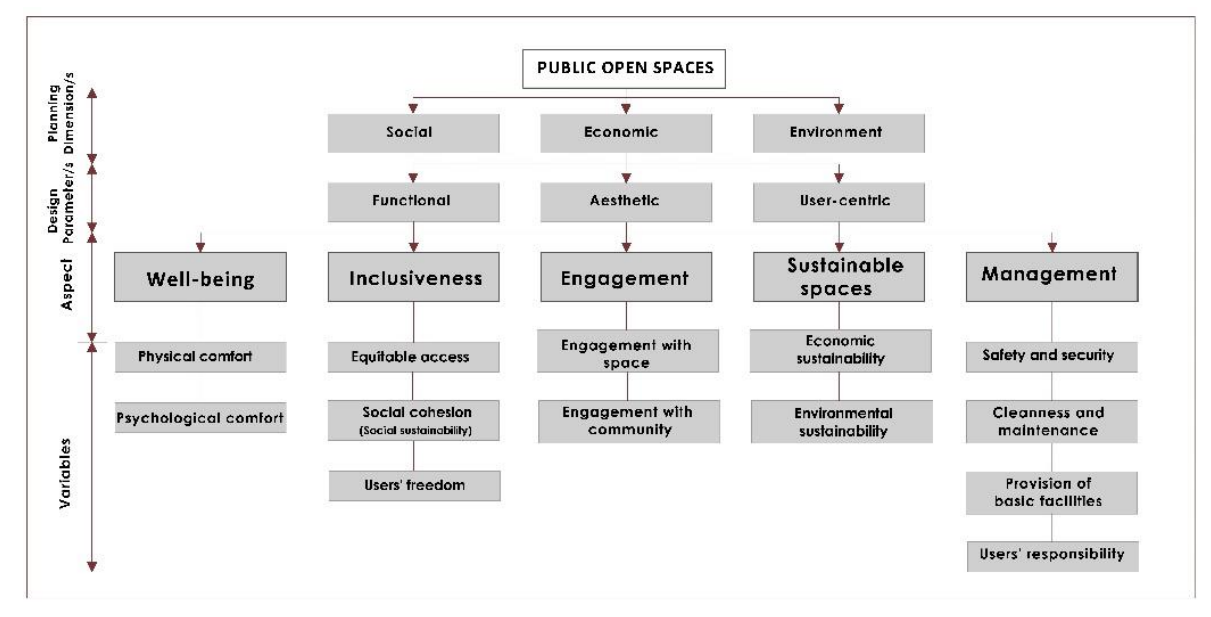

Figure 2. Analytical framework considered for the study.

\section{Methods}

\subsection{Study Area}

Nagpur is located at $21.15^{\circ} \mathrm{N} 79.08^{\circ} \mathrm{E}$ and is the third largest city in the Indian state of Maharashtra. The city has recorded a population of 2.4 million and a literacy rate of 92\% in the census-2011 [75]. People from neighbouring districts come and settle in the city for opportunities such as education, employment and business. The City Development Plan-2041 (CDP-2041) prepared by Nagpur Municipal Corporation (NMC) predicts 29\% and 35\% of population growth in the coming years 2021 and 2031, respectively. CDP-2041 also stated that the city of Nagpur suffers from an acute shortage of POSs and the current space-person ratio is below national and international standards. The city encompasses a mix of cultural, social and income communities. The demographic pattern of the city and the issues of POSs are similar to other major cities. Therefore, the city of Nagpur was considered a representative example and selected for the study.

According to the information received from NMC officials, the Garden Department is responsible for the construction, operation, and maintenance of the POSs. The city included a larger number of NMC's own free access POSs than paid access POSs. Pilot study observations indicated that paid access POSs are more maintained, clean and provide different facilities and services to users than POSs that offer free access. Some of the free access POSs were confronted with issues such as inadequate maintenance, poor artificial lighting, untidiness, debris, littering, and broken furniture and pathways. Observations also suggest that most citizens prefer to visit free access POSs for yoga, walking, exercise, and roaming as part of their ordinary routine. With the help of factors such as pilot study observations, citizens' preference for visits and availability in higher numbers, it was decided to consider free access POSs for the main study. Two free access POSs; namely, Major Surendra Deo Park (MSDP) and Rajiv Gandhi Park (RGP) with an area of 4.97 and 8.0 acres, were selected on the basis of a specific criterion. The criterion examined area, ownership, daily footfall, and adjacent neighbourhood. Preference was given to POSs that were surrounded by commercial activity and residences from various social, cultural, and economic groups. Such diversity encouraged the researcher to cover a wide range of information in the study, such as visitation patterns, space use, users' activities, and their perceptual opinion of space. Both POSs are normally open to the public from 5:30 a.m. to 10:00 a.m. (morning) and from 4:30 p.m. to 8:30 p.m. (evening). Figure 3 shows the location of both POSs. In addition, Figure 4 shows both POSs and their surrounding area. 


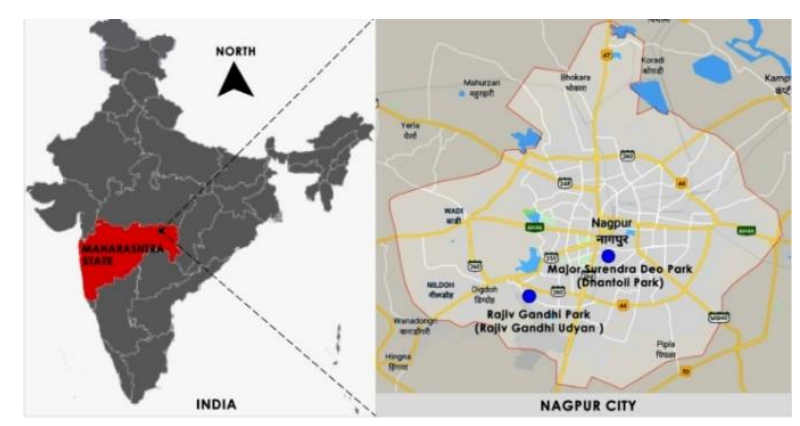

Figure 3. Location map.

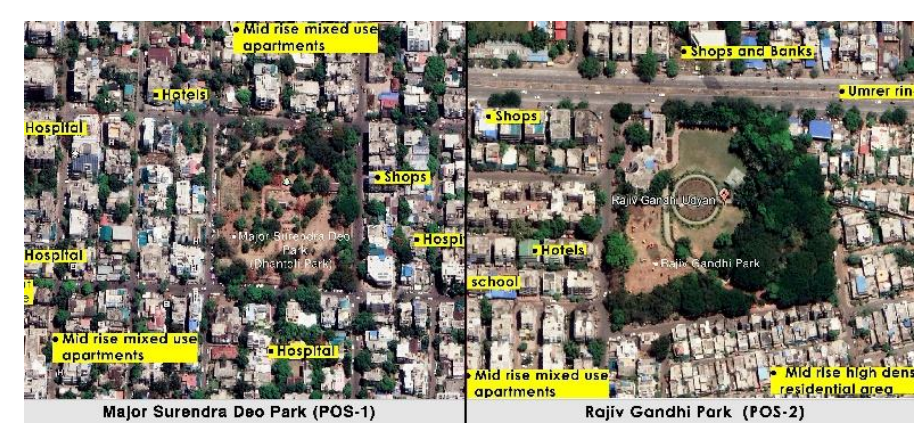

Figure 4. MSDP(POS-1) and RGP(POS-2).

\subsection{Data Collection}

A mixed methods approach was used for data collection. According to Tashakkori and Teddlie [76] and Creswell and Clark [77], mixed methods incorporate the strengths of both qualitative and quantitative methods, which aid in the collection of data from multiple perspectives, improves the findings' accuracy, validity, reliability, and provides a better understanding of the study. The study employed a self-administered questionnaire survey andobservation. A self-administered questionnaire survey, a quantitative approach that helps to understand the users' perceptions of POS. A self-administered questionnaire survey allows the researcher to gain a better understanding of a POS's functional and aesthetic capabilities from the perspective of users $[43,59,63]$. Aself-administered questionnaire assists respondents to complete the response themselves without the intervention of the researcher. It is consideredas an appropriate platform for users to freely express their opinions. Moreover, a self-administered questionnaire survey has advantages over other data collection methods that are inexpensive and take less time [63]. Scholars such as Mehta [43], Zamanifard et al. [59] and Askari et al. [63], have used questionnaire surveys to determine users' opinions and demonstrated their suitability for similar studies. Observation, a qualitative approach, was used to analyse active-passive activities, user behaviour, facilities, and services provided within space. According to Kothari [78], an observation helps to eliminate subjective bias, if used correctly. It aids in understanding the current situation or status of POS and requires less active cooperation from other people. Scholars such as Whyte [28] and Gehl [62] have used an observation to identify significant characters of POSs in their studies.

The public open space index (POSI) included five aspects, thirteen variables and forty-five measuring items. Out of these, users rated twenty-four measuring items through their perception and the researcher rated twenty-one items by observation. The researcher had prepared two separate sheets, i.e. the self-administered questionnaire for respondents, and the observation sheet for himself. Measuring items were rated with the help of a five point 'Likert scale' on both sheets. The scale was organised as, ' $1=\mathrm{No}^{\prime}$, ' $2=$ Somewhat', '3 = Moderate', ' $4=$ Mostly', and ' $5=$ Yes'. The Likert scale obtains an intelligence response and is commonly used in questionnaire surveys [77]. Scholars have recommended such 
type of scaling in similar studies $[43,62,63]$. The questionnaire survey and observation were conducted multiple times a day and week; therefore, the mean score was considered for the result. In each aspect of POSI, different numbers of measuring items were included; hence, the individual aspect score and the overall mean score (summation of all five aspects' score) were converted into a percentage to ensure the uniformity of the result. The study also proposed a ranking for the analysis of the percentage score as: Below $50 \%$-'Poor' $^{\prime}, 50 \%$ to

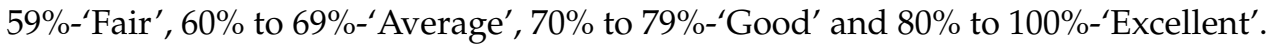

The pilot study helps to check the capability of tools and to identify errors in the survey [79]. It was carried out with 30 users in the first week of July 2019 to check the time taken by respondents to fill out the questionnaire, efficiency, wording of the questionnaire and participants' interest in the survey. Based on the experience of the pilot survey, some of the questions were reconstructed in simple terms in the main survey in order to improve the understanding of the respondents. This method helped to improve the reliability of the main survey. Due to the vague ward population of government records and the non-existence of register (to track user entry and exit) at the entrance of POSs, the weekly footfall of the individual POS was counted and considered to identify the sample size. Values such as the weekly footfall, a confidence level of $95 \%$, and margin of error $-/+5 \%$ were considered to determine the sample size [80,81].

The researcher and two architecture graduate attendees conducted the main survey. A person aged 18 and above was considered eligible to respond to the questionnaire survey. At the main entrance of POSs, the researcher informed users about the aim of the study and requested them to participate in the survey. Users, who expressed an interest received a questionnaire. Participation was voluntary, and no incentive was offered to the respondents. Scholars have adopted and recommended such a method in similar studies [82,83]. A total of 290 from MSDP and 263 from RGP respondents participated in the main survey. Data was collected over the simultaneous period of 2-13 September 2019 (twelve days) in MSDP and 14-27 September 2019 (fourteen days) in RGP. On average, respondents completed 24 questionnaires per day.The response ratio was 4 to 1 , implying that one out of every four users expressed an interest in participating in the survey.

The Social Sciences Statistical Package (SPSS, version-25) was used for data analysis. A descriptive statistical method was used to determine mean, standard deviation, and percentage. Cronbach's reliability and Pearson's correlation coefficient were performed to identify the relationship between measuring items.

\section{Results}

The study is formulated to identify the strengths and deficiencies of POSs. Accordingly, the results are described in three sections.

\subsection{Respondent Characteristics and POSs Visitation}

A total of 553 questionnaires were filled out by respondents from both POSs. The response rate of male participants was higher than that of females. Users in the age groups 25 to 39 gave a higher response to the survey. All 553 respondents were educated and $47.20 \%$ were degree holders. Most of the respondents were working in the private sector, followed by self-employed people and then government servants. Table 1 shows respondent characteristics in detail. 
Table 1. Respondent characteristics.

\begin{tabular}{|c|c|c|c|c|c|}
\hline \multirow[t]{2}{*}{ Sr.No. } & \multirow[t]{2}{*}{ Characteristics } & \multicolumn{2}{|c|}{$\begin{array}{c}\text { MSDP ( POS-1) } \\
\quad(n=290)\end{array}$} & \multicolumn{2}{|c|}{$\begin{array}{l}\text { RGP (POS-2) } \\
\quad(n=263)\end{array}$} \\
\hline & & Count & Percentage & Count & Percentage \\
\hline \multirow[t]{3}{*}{1} & Gender & & & & \\
\hline & Male & 165 & 56.89 & 166 & 63.11 \\
\hline & Female & 125 & 43.1 & 97 & 36.88 \\
\hline \multirow[t]{5}{*}{2} & Age group & & & & \\
\hline & $18-24$ years & 51 & 17.6 & 55 & 20.9 \\
\hline & 25-39 years & 101 & 34.8 & 99 & 37.6 \\
\hline & $40-59$ years & 78 & 26.9 & 66 & 25.1 \\
\hline & 60 years and older & 60 & 20.7 & 43 & 16.3 \\
\hline \multirow[t]{8}{*}{3} & Education level & & & & \\
\hline & School & 13 & 4.5 & 8 & 3.0 \\
\hline & Junior College & 55 & 19.0 & 42 & 16.0 \\
\hline & Degree & 133 & 45.9 & 128 & 48.7 \\
\hline & Post graduation & 61 & 21.0 & 52 & 19.8 \\
\hline & Doctorate & 21 & 7.2 & 22 & 8.4 \\
\hline & Post Doctorate & 7 & 2.4 & 11 & 4.2 \\
\hline & Not visited school & 0 & 0.0 & 0 & 0.0 \\
\hline \multirow[t]{8}{*}{4} & Occupation & & & & \\
\hline & Government servant & 48 & 16.6 & 24 & 9.1 \\
\hline & Private Sector & 112 & 38.6 & 96 & 36.5 \\
\hline & Self Employed & 67 & 23.1 & 52 & 19.8 \\
\hline & Retired & 9 & 3.1 & 26 & 9.9 \\
\hline & Student & 24 & 8.3 & 31 & 11.8 \\
\hline & Housewife & 21 & 7.2 & 17 & 6.5 \\
\hline & Not working/Searching for Job & 9 & 3.1 & 17 & 6.5 \\
\hline 5 & Footfall measured in one week & 1172 & & 852 & \\
\hline
\end{tabular}

Source: SPSS (version 25).

The study also recorded the users' visit frequency inthese spaces. The analysis of the results showed that most users visited POSs a few times a week. These users were engaged in active, passive, and other social activities. The survey recorded a higher percentage of users in this category, i.e., $43 \%$ and $42 \%$ in MSDP and RGP, respectively. Users who visited POSs once a day reported $24 \%$ in MSDP and $25 \%$ in RGP. This category includes those engaged in physical activities such as yoga, walking, jogging, and open gym exercise. Another analysis indicated that users living at a distance of $0.5 \mathrm{~km}$ to $2.0 \mathrm{~km}$ from POSs visited spaces higher than users living at a long distance. This group accounted for $38 \%$ of MSDP users and $40 \%$ of RGP users. Users who reside at a distance of $5.0 \mathrm{~km}$ and more usually prefer to visit spaces occasionally.

\subsection{Public Open Space Index [POSI] Score Received by POSs}

First, describing aspect wise result; both POSs received 'poor' rank in Individual wellbeing aspect. Here, MSDP and RGP earned $48.29 \%$ and $45.13 \%$, respectively. Whereas, both POSs gained 'fair' rank in Inclusiveness and Sustainable spaces aspects, in these aspects, MSDP scored $51.37 \%$, and $55.75 \%$ and RGP received $56.02 \%$ and $57.64 \%$, respectively. RGP scored 'average' rank in Engagement and Management aspects. Here, RGP received $64.76 \%$ and $63.83 \%$, respectively. MSDP got 'fair' rank in Engagement and 'poor' rank in Management by getting $56.25 \%$ and $44.29 \%$ respectively. Next, describing the total POSI score (i.e. summation of all five aspects scores), MSDP and RGP earned $50.67 \%$ and $57.30 \%$ with a 'fair' ranking. The overall result shows that there is a need for improvement in both spaces. Figure 5 indicates the aspect wise POSI score received by both POSs. In addition, the POSI score received by both POSs is shown in Table A1 in Appendix A. 


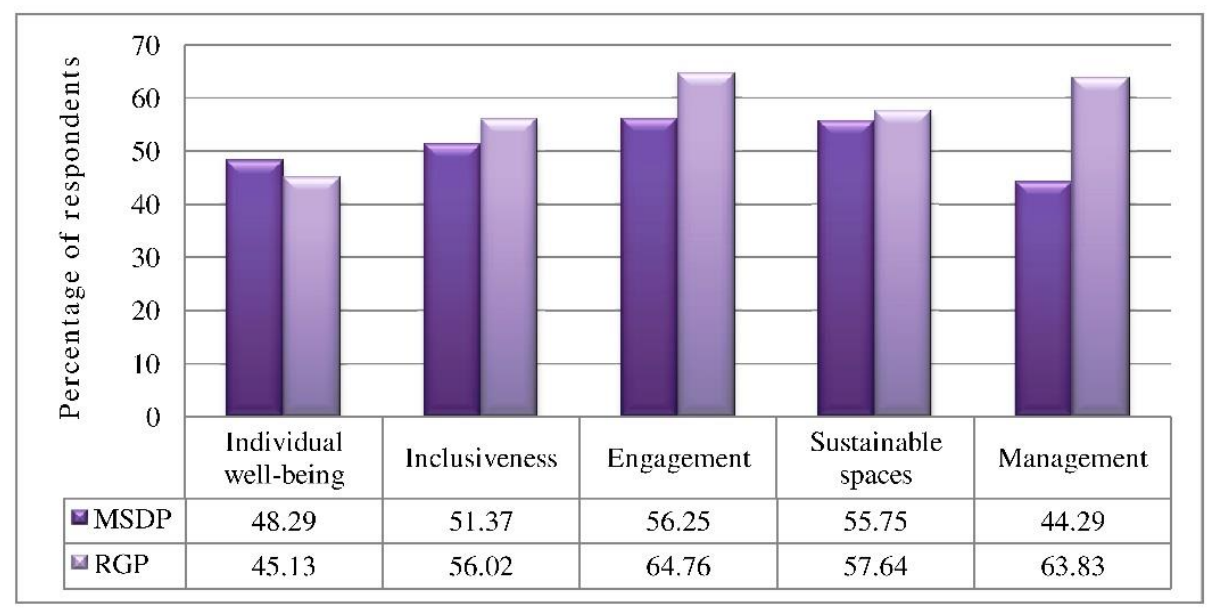

Figure 5. POSI score received by aspects (Percentage).

Results now describe the variable wise score obtained by POSs. In the individual well-being aspect, MSDP achieved a high score in the 'physical comfort' variable. The variable assessed the capacity of POSs to provide convenient entry, walkways, open and shaded areas, arrangement of seating, and shelter. It also checked whether all age groups used the space effectively or not. In the same aspect, RGP gained a high score in the variable 'psychological comfort'. It assessed the availability of elegant architecture and landscape features, attractive and pleasant views. The variable also evaluated the availability of noise buffer zone in combination with planting vegetation in order to reduce outside traffic noise that gives users peace, ease, and pleasure. Simultaneously, in the aspectInclusiveness, both POSs received almost equal scores in the variable 'equitable access'. The variable evaluated the potentiality of POSs to promote diversity and Universal Design. In the same aspect, RGP received a high score in 'social cohesion'. It assessed whether or not POSs provided opportunities for users to participate in various events and programmes, encouraged positive conversations, shared experiences, a sense of community, and a sense of pride.

In the aspect Engagement, RGP received higher scores in variables, 'engagement with space' and 'engagement with community'. Users argued that the design and layout of RGP is appropriate for them and is therefore rated higher. The variable 'engagement with space' assessed space versatility to adapt changes to the needs of users, space capacity to encourage a variety of activities, and the appropriateness of the design and layout of space for users. The variable also checked whether the space had active and vibrant edges to encourage engagement with food, shopping, and entertainment. Another variable, 'engagement with community', has indicated that RGP promotes social activities, interactions, local culture, and the arts. Therefore, it received a high score. The result of the aspect Sustainable Spaces has shown that both POSs have scored well in the variable 'economic sustainability.' The variable checked whether or not POSs contribute to the enhancement of businesses around them, such as shopping, hotels and street food. It also ensured that POSs helped to minimise the overall cost of living by providing access to community services, utilities and leisure facilities.The variable ensured space would lead to a reduction in health expenditure for users, whereas both POSs had a low score in the variable 'Environmental sustainability' due to poor adoption of sustainable practises such as the use of renewable energy resources, rainwater harvesting, waste management and a water-efficient irrigation system. Observation has also shown that the two POSs do not promote sustainable landscape practise.

In Management, RGP scored high in variables, 'users' responsibility, ' 'provision of basic facilities' and 'safety and security'. The result of these variables indicated that RGP provides more facilities and safety to its users. Observations suggested that users of RGP 
showed respect for space and acted in a civil, appropriate and responsible manner. Figure 6 describes the comparative radar diagram showing all variables' scores.

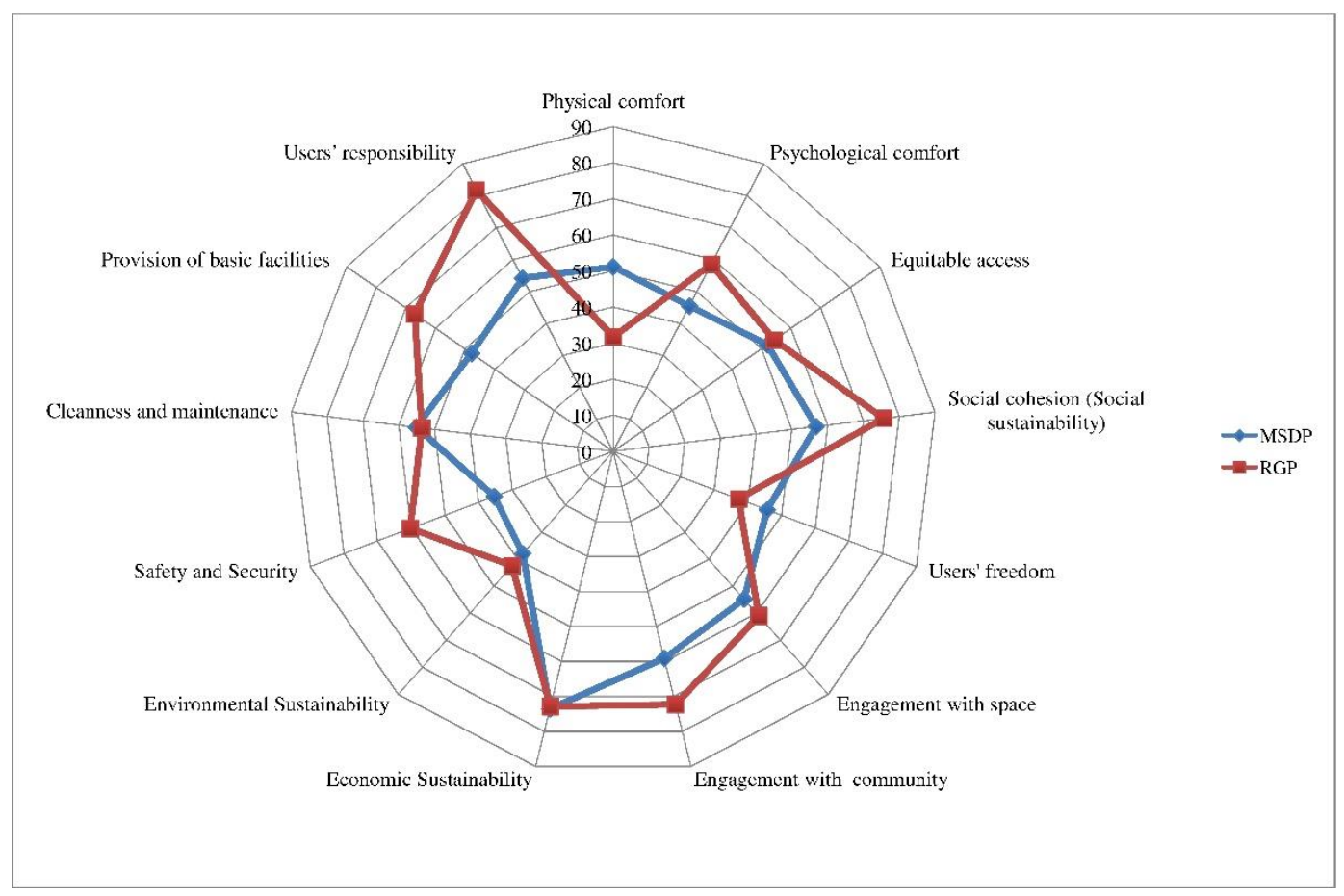

Figure 6. Comparative radar diagram showing all variables' score.

\subsection{Reliability Analysis and a Correlation between Measuring Items}

The study deals with latent variable 'perception'. Measuring items formulated in the study are directly and indirectly associated with the unobserved variable, perception. Therefore, it was essential to ensure the internal consistency of all the items. Cronbach's alpha is one way of measuring the strength of consistency. It furthermore demonstrates whether the scale constructed for research is fulfilling its purpose or not. According to Ryan [84], the efficiency of Cronbach's alpha should be 0.70 or more to consider it as 'acceptable'. Table 2 shows the reliability analysis of both POSs together.

Table 2. Reliability analysis.

\begin{tabular}{ccccc}
\hline Sr.No. & POSs Name & Sample Size (n) & Number of Measuring Items & Cronbach's Alpha $(\boldsymbol{\alpha})$ \\
\hline 1 & MSDP & 290 & 45 & 0.730 \\
\hline 2 & RGP & 263 & 45 & 0.776 \\
\hline
\end{tabular}

Source: SPSS (version-25).

Pearson bivariate correlation analysis was conducted to support the hypothesis of the study. It assists the researcher to identify the correlation between two variables. Table 3 indicates the correlation between the available facilities, services, and aesthetic appearance of the space (independent variable) and respondents' perceptional response (dependent variable). It shows that both independent and dependent variables are closely related to each other. It proved the hypothesis of the study. 
Table 3. Correlation between Space facilities, services, and aesthetic appearance and users' perception.

\begin{tabular}{|c|c|c|c|c|c|c|}
\hline \multirow[b]{2}{*}{ Sr.No } & \multirow{2}{*}{$\begin{array}{l}\text { Space Facilities, Services, } \\
\text { and Aesthetic Appearance } \\
\text { (Independent Variable) }\end{array}$} & \multirow{2}{*}{$\begin{array}{l}\text { Respondents' } \\
\text { Perception } \\
\text { (Dependent } \\
\text { Variable) } \\
\end{array}$} & \multicolumn{2}{|c|}{$\operatorname{MSDP}(\operatorname{POS}-1)(n=290)$} & \multicolumn{2}{|c|}{ RGP $(\operatorname{POS}-2)(n=263)$} \\
\hline & & & $\begin{array}{c}\text { Pearson } \\
\text { Correlation }\end{array}$ & Sig.(2-Tailed) & $\begin{array}{l}\text { Pearson } \\
\text { Correlation }\end{array}$ & Sig.(2-Tailed) \\
\hline 1 & $\begin{array}{l}\text { POS offers attractive and } \\
\text { pleasant views }\end{array}$ & $\begin{array}{l}\text { POS makes a } \\
\text { perceivable and } \\
\text { positive image }\end{array}$ & $0.240^{* *}$ & 000 & $405^{* *}$ & 000 \\
\hline 2 & $\begin{array}{c}\text { Space encourages a variety of } \\
\text { activities: active, passive and } \\
\text { other }\end{array}$ & $\begin{array}{l}\text { User spends } \\
\text { quality time in } \\
\text { this space }\end{array}$ & $0.525 * *$ & 0.000 & $0.266^{* *}$ & 0.000 \\
\hline 3 & $\begin{array}{l}\text { Space needs more safety } \\
\text { arrangements: Security } \\
\text { guards, Lights and } \\
\text { CCTV }\end{array}$ & $\begin{array}{l}\text { Users feel safe } \\
\text { within space }\end{array}$ & -0.133 * & 0.024 & $-0.343^{* *}$ & 0.000 \\
\hline 4 & $\begin{array}{l}\text { Design and layout of space } \\
\text { appropriate for users }\end{array}$ & $\begin{array}{l}\text { Space is capable } \\
\text { of fulfilling } \\
\text { people's needs }\end{array}$ & $0.513^{* *}$ & 0.000 & $0.186^{* *}$ & 0.003 \\
\hline 5 & $\begin{array}{c}\text { Space provides access to } \\
\text { community services, } \\
\text { amenities, and leisure } \\
\text { facilities. }\end{array}$ & $\begin{array}{l}\text { Space leads to } \\
\text { the reduction of } \\
\text { health } \\
\text { expenditure }\end{array}$ & $-0.495^{* *}$ & 0.000 & $-0.125^{*}$ & 0.034 \\
\hline
\end{tabular}

**. Correlation is significant at the 0.01 level (2-tailed). *. Correlation is significant at the 0.05 level (2-tailed).Source: SPSS (version-25).

\section{Discussion}

The results showed a statistical analysis of the data collected through a self-administered questionnaire survey and observation. The discussion section interprets the results and identifies the strengths and deficiencies of the POSs that affect their character and use. Some measuring items received high scores from users and researcher.These measuring items have been considered as strengths of POSs. Items those received poor scores indicated deficiencies of POSs.

Both POSs scored less than $60 \%$ in the overall results. In the aspect individual wellbeing, POSs provide users with easy access.Elegant architectural elements such as sculpture, water fountains, landscape, and aesthetically rich furniture are included in POSs. According to observations, people are using POSs effectively. MSDP users argued that POS provides them with visual pleasure. They enjoy visiting space to experience attractive and pleasant views that relax them. The results identified a positive relationship between attractive and pleasant views and users' perceptions of space $\left(\mathrm{r}=0.240^{* *}\right.$ and $\left.405^{* *}, p \leq 0.01\right)$. Whyte [28] and Mehta [43] explained that attractive and pleasant views provide psychological comfort to their users. Furthermore, both POSs have wide, single-level walkways that allow multiple users to use the space. Now explaining deficiencies, POSs have poor climateresponsive design. Marcus and Francis [2], Shaftoe [39], and Carr et al [24] stressed the importance of microclimate in their studies. The lack of semi-covered seating and shelter arrangements makes it difficult for users to use these spaces throughout the year. Morever, users of both POSs claimed they could hear outside traffic noise. Both POSs received lower scores on these measuring items. These deficiencies could be addressed by providing open and covered seating/gathering areas, as well as shelters, in POSs. Furthermore, various design innovations must be implemented within POSs in order to reduce external noise, e.g. planting dense and thick buffer strips of shrubs and trees between the POS and the noise source, creating soil berms, or constructing a wall made of brick, stone, or concrete.

The result of 'Inclusiveness' revealed that both POSs allow people to enter regardless of their age, gender, religion, or social economic status. POSs also arrange different events and programmes, and encourage people to participate in them. RGP users argued space encourages a fun atmosphere for social networking, positive conversation, and 
experience sharing. According to users, such an environment fosters a sense of belonging, confidence, acceptance, and connectivity among people and contributes to social cohesion. Holland et al. [54], Moulay et al. [55], and Jennings and Bamkole [57] explained similar observations in their studies. Some measuring items highlighted deficiencies, e.g. both POSs do not follow the practice of Universal Design. POSs do not have ramps, walkways with tactile flooring, making it difficult for people with physical disabilities to use POSs. Wolfgang and Ostroff [55] argued it is essential to follow the practice of Universal Design, in particular when planning and creating public spaces. Furthermore, users have requested to extend the POSs' operating hours so that the maximum number of people can make the most of their visits and spend a little more time in space. In the aspect 'Engagement', MSDP promotes active and passive activities. The results indicated that POS activities have a positive relationship with users' quality time $\left(\mathrm{r}=0.525^{* *}\right.$ and $\left.0.266^{* *}, p \leq 0.01\right)$. It means a wide range of activities inside the space encourages people to spend quality time there. According to the observations, RGP has the flexibility to respond to the needs of users.POS can change and adjust its layout to meet the diverse needs of users. Scholars such as Carr et al. [24] and Carmona et al. [38] suggested the feature to enhance the affection between POS and users. RGP also provides users with interaction opportunities. These strengths encourage users' effective engagement with the space and the community. Both POSs do not have active and vibrant edges. Activities such as food, shopping, and entertainment need to be incorporated at the edges of POSs. These activities provide 'liveliness' to POSs and attract more people to them.

Concerning the aspect'Sustainable spaces', the results indicate that access to community services, utilities, and recreational facilities has a negative relationship with user health costs $\left(\mathrm{r}=-0.495^{* *}, p \leq 0.01\right.$ and $\left.-0.125^{*}, p \leq 0.05\right)$. It means that when users gain access to community services, utilities, and recreational facilities, their healthcosts decrease, or vice versa. According to observations, POSs have also helped in the financial improvement of the local businesses that are located around them. These are the POSs' strengths in promoting economic sustainability $[17,18,31]$. In addition, both POSs are linked to other parts of the city by large walkways and public transportation. This connectivity allows people to walk and take public transportation, reducing the use of personal vehicles and fuel consumption. While talking about deficiencies, POSs do not encourage sustainable practices that include the use of renewable energy resources, rainwater harvesting, waste management, and a water-efficient irrigation system. Sustainable landscape practices such as the use of native plants, xeriscaping, and the preservation of natural topography have also been poorly introduced by POSs. These deficiencies increase the use of electricity and water, produce solid waste, and contribute to soil degradation. According to Blowers [68] and Selman [69], sustainable practices are a critical need of the twenty-first century in order to protect natural resources and the environment.

In the aspect 'Management', both POSs encourage user responsibility, safety and security, and the provision of basic facilities. Users arguedthey felt secure in POSs during the day and evening hours [32,71]. The results showed that the demand for safety arrangements has a negative relationship with the perception of users as a safe space $\left(\mathrm{r}=-0.133^{*}, p \leq 0.05\right.$ and $\left.-0.343^{* *}, p \leq 0.01\right)$. Users perceive space as safe, the demand for safety arrangements decreases or vice-versa.In addition, users argued they perceived space as clean, neat, and well maintained. It has also been observed that users of both POSs show respect for spaces. They helped to maintain a healthy public realm [44]. POSI identified a number of deficiencies in both POSs. Both POSs do not encourage passive control, including the display of written or symbolic instructions to prevent unwanted activities. Furthermore, POSs do not include the display of helpline numbers such as police station, women's and childcare, and medical service near the entrance. This type of display is required to increase user awareness and should be installed. A summary of strengths and deficiencies for all five aspects is shown in Table A2 in Appendix A. 


\section{Conclusions}

POSs are one of the key components in urban areas that contribute to improving the quality of life of citizens. The results demonstrate that the characteristics of POSs, such as the built environment, aesthetics, facilities, services and maintenance have an impact on people's use and perception. These characteristics are responsible for inviting a wide range of users and providing them with a psychological and physical console. The study proposed the Public Open Space Index (POSI) for assessing POSs. The study promotes planning dimensions such as social, economic, and environmental, as well as design parameters such as functional, aesthetic and user-centric approaches by considering them in the formation of the POSI. Furthermore, the study provides a common platform for users to share their perceptions of POSs. In this way, it encourages users to participate in the design process. The study also encourages the government authority to adopt a comprehensive design strategy for the development of sophisticated POSs within the city.

This study has outlined the importance of qualitative POSs. It is considered essential in India, where a large population depends on a limited number of POSs, and cities include a wide range of users with diverse needs and choices. POSI reveals, both POSs include some strengths that attract footfall towards them. POSs also have some deficiencies that must be addressed with effective measures. The study will have practical implementation. It develops modern ideas for the design of POSs. It indicates that although the available POSs are inadequate in quantity, proper initiatives will improve their character and use, and enable them to serve different facilities at their optimum level. When inclusive, functional, and aesthetically strong POSs emerge within cities and satisfy the needs of users, they convey accurate expressions to sustain a healthy public life. This study has a limitation. It focuses solely on public parks. The city has other POSs, such as squares, playgrounds and riverside, which also need to be assessed in order to improve their character and use. Subsequent studies can be developed with these spaces to identify their strengths and deficiencies.

Author Contributions: Methodology, P.A.; software, P.A.; writing—original draft, P.A.; writingreview and editing, P.A.; supervision, S.K. All authors have read and agreed to the published version of the manuscript.

Funding: This research received no external funding.

Institutional Review Board Statement: Not Applicable.

Informed Consent Statement: Informed consent was obtained from all subjects involved in the study.

Data Availability Statement: The study did not report any data.

Acknowledgments: This research is funded by the scholarship awarded to Pritam Ahirrao from Ministryof Human Resource Development (MHRD), Government of India. We would like to thank Jeanie Wang and two anonymous reviewers for their constructive comments that help us to improve the manuscript.

Conflicts of Interest: The authors declare no conflict of interest. 


\section{Appendix A}

Table A1. Public Open Space Index (POSI) score received by POSs.

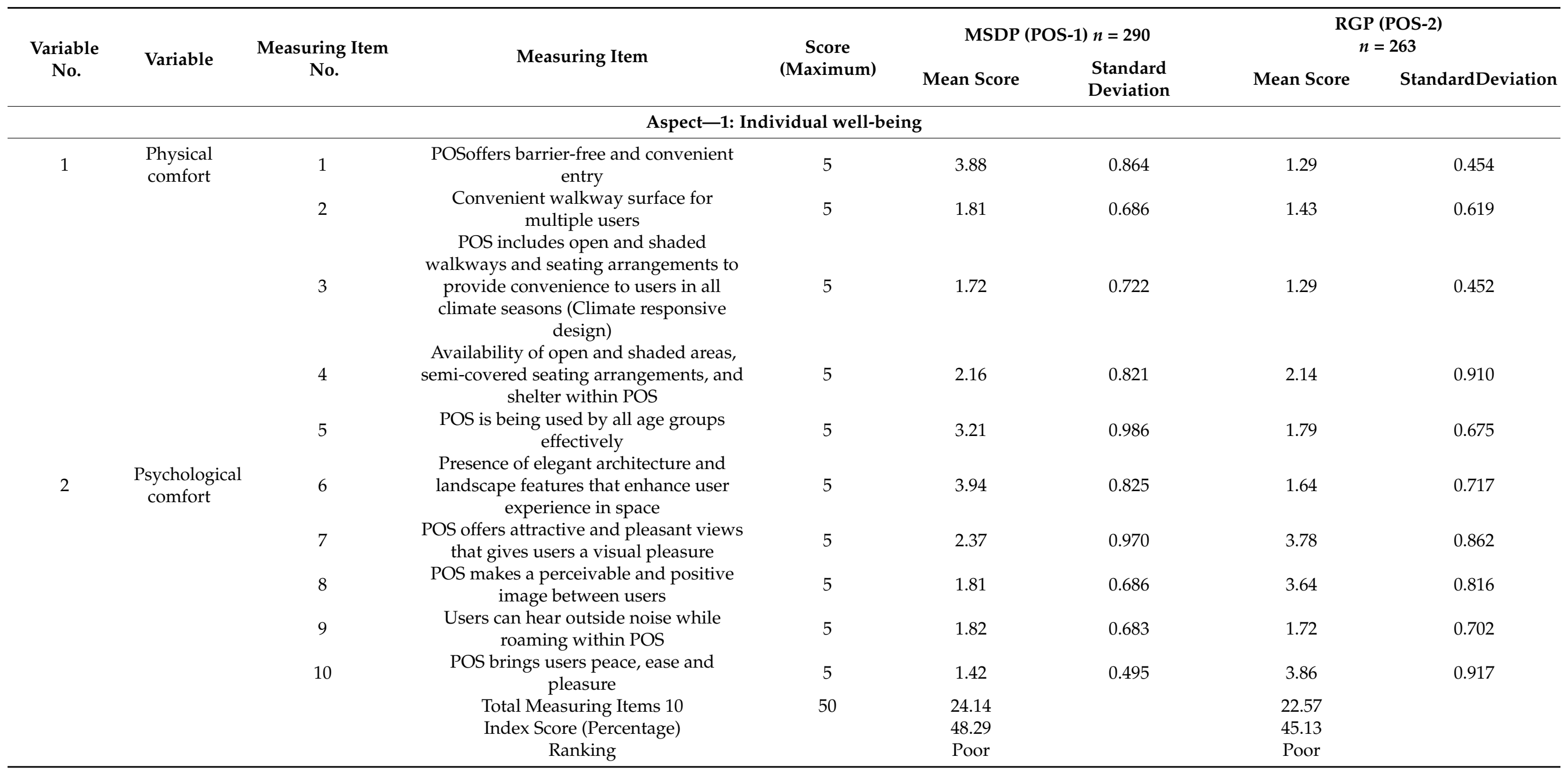


Table A1. Cont.

\begin{tabular}{|c|c|c|c|c|c|c|c|c|}
\hline \multirow{2}{*}{$\begin{array}{c}\text { Variable } \\
\text { No. }\end{array}$} & \multirow{2}{*}{ Variable } & \multirow{2}{*}{$\begin{array}{c}\text { Measuring Item } \\
\text { No. }\end{array}$} & \multirow{2}{*}{ Measuring Item } & \multirow{2}{*}{$\begin{array}{c}\text { Score } \\
\text { (Maximum) }\end{array}$} & \multicolumn{2}{|c|}{ MSDP (POS-1) $n=290$} & \multicolumn{2}{|c|}{$\begin{array}{l}\text { RGP (POS-2) } \\
\quad n=263\end{array}$} \\
\hline & & & & & Mean Score & $\begin{array}{c}\text { Standard } \\
\text { Deviation }\end{array}$ & Mean Score & StandardDeviation \\
\hline \multicolumn{9}{|c|}{ Aspect 2: Inclusiveness } \\
\hline \multirow[t]{2}{*}{3} & $\begin{array}{l}\text { Equitable } \\
\text { access }\end{array}$ & 11 & $\begin{array}{l}\text { POS provides equitable access to all } \\
\text { people, regardless of age, gender, } \\
\text { religion or social economic status } \\
\text { (Promotes Diversity) }\end{array}$ & 5 & 3.86 & 0.960 & 4.29 & 0.699 \\
\hline & & 12 & $\begin{array}{c}\text { Availability of ramp, and tactile } \\
\text { flooringprovide convenience to users } \\
\text { with physical disabilities ( Promotes } \\
\text { Universal Design) }\end{array}$ & 5 & 1.34 & 0.474 & 1.14 & 0.352 \\
\hline \multirow[t]{3}{*}{4} & $\begin{array}{l}\text { Social } \\
\text { cohesion } \\
\text { (Social sus- } \\
\text { tainability) }\end{array}$ & 13 & $\begin{array}{l}\text { POS provides an opportunity to } \\
\text { participate in events and programmes }\end{array}$ & 5 & 3.62 & 0.912 & 4.00 & 0.929 \\
\hline & & 14 & $\begin{array}{l}\text { User feels like a part of the POS } \\
\text { community (Sense of community) }\end{array}$ & 5 & 2.30 & 0.874 & 3.64 & 1.113 \\
\hline & & 16 & $\begin{array}{l}\text { People are proud to have such space in } \\
\text { their neighbourhood (Sense of Pride) }\end{array}$ & 5 & 2.89 & 1.570 & 3.79 & 1.012 \\
\hline \multirow[t]{7}{*}{5} & $\begin{array}{l}\text { Users' } \\
\text { freedom }\end{array}$ & 17 & $\begin{array}{l}\text { User feel free about his/her behaviour in } \\
\text { space }\end{array}$ & 5 & 2.63 & 0.879 & 1.57 & 0.625 \\
\hline & & 18 & $\begin{array}{l}\text { Space enables users to freely roam } \\
\text { without restrictions }\end{array}$ & 5 & 2.87 & 0.809 & 1.93 & 0.706 \\
\hline & & 19 & $\begin{array}{l}\text { Surveillance cameras, security guards, } \\
\text { etc. infringe the privacy of users }\end{array}$ & 5 & 2.31 & 0.853 & 2.72 & 1.161 \\
\hline & & 20 & $\begin{array}{l}\text { Users are pleased with the opening } \\
\text { hours of space }\end{array}$ & 5 & 1.32 & 0.469 & 1.22 & 0.413 \\
\hline & & & Total Measuring Items 10 & 50 & 25.69 & & 28.01 & \\
\hline & & & Index Score (Percentage) & & 51.37 & & 56.02 & \\
\hline & & & Ranking & & Fair & & Fair & \\
\hline
\end{tabular}


Table A1. Cont.

\begin{tabular}{|c|c|c|c|c|c|c|c|c|}
\hline \multirow{2}{*}{$\begin{array}{l}\text { Variable } \\
\text { No. }\end{array}$} & \multirow{2}{*}{ Variable } & \multirow{2}{*}{$\begin{array}{l}\text { Measuring Item } \\
\text { No. }\end{array}$} & \multirow{2}{*}{ Measuring Item } & \multirow{2}{*}{$\begin{array}{c}\text { Score } \\
\text { (Maximum) }\end{array}$} & \multicolumn{2}{|c|}{ MSDP (POS-1) $n=290$} & \multicolumn{2}{|c|}{$\begin{array}{l}\text { RGP (POS-2) } \\
\quad n=263\end{array}$} \\
\hline & & & & & Mean Score & $\begin{array}{l}\text { Standard } \\
\text { Deviation }\end{array}$ & Mean Score & StandardDeviation \\
\hline \multirow[t]{6}{*}{6} & \multirow[t]{6}{*}{$\begin{array}{l}\text { Engagement } \\
\text { with space }\end{array}$} & 21 & $\begin{array}{l}\text { Space is capable of fulfilling people's } \\
\text { needs (Local needs) }\end{array}$ & 5 & 2.31 & 1.385 & 2.22 & 1.325 \\
\hline & & 22 & $\begin{array}{l}\text { Space versatility to adapt changes to the } \\
\text { needs of users }\end{array}$ & 5 & 2.57 & 1.064 & 4.44 & 0.620 \\
\hline & & 23 & $\begin{array}{l}\text { Space encourages a variety of activities: } \\
\text { active, passive and other }\end{array}$ & 5 & 4.27 & 0.774 & 3.28 & 0.885 \\
\hline & & 24 & $\begin{array}{l}\text { Design and layout of space appropriate } \\
\text { for users }\end{array}$ & 5 & 2.24 & 1.093 & 3.06 & 1.032 \\
\hline & & 25 & $\begin{array}{l}\text { More activities are required in this space } \\
\text { Space has active and vibrant edges to }\end{array}$ & 5 & 3.79 & 0.986 & 4.15 & 0.739 \\
\hline & & 26 & $\begin{array}{l}\text { encourage food, shopping and } \\
\text { entertainment }\end{array}$ & 5 & 1.26 & 0.437 & 1.14 & 0.352 \\
\hline \multirow[t]{6}{*}{7} & \multirow[t]{6}{*}{$\begin{array}{l}\text { Engagement } \\
\text { withcom- } \\
\text { munity }\end{array}$} & 27 & $\begin{array}{c}\text { Space encourages social activities and } \\
\text { interaction }\end{array}$ & 5 & 3.03 & 1.149 & 3.28 & 1.029 \\
\hline & & 28 & Space encourage local culture and arts & 5 & 3.05 & 1.143 & 3.93 & 0.703 \\
\hline & & 29 & User spends quality time in this space & 5 & 2.79 & 1.244 & 3.63 & 1.237 \\
\hline & & & Total Measuring Items 9 & 45 & 25.31 & & 29.14 & \\
\hline & & & Index Score (Percentage) & & 56.25 & & 64.76 & \\
\hline & & & Ranking & & Fair & & Average & \\
\hline \multicolumn{9}{|c|}{ Aspect 4: Sustainable spaces } \\
\hline \multirow[t]{3}{*}{8} & $\begin{array}{l}\text { Economic } \\
\text { Sustain- } \\
\text { ability }\end{array}$ & 30 & $\begin{array}{c}\text { Space contributes to enhance } \\
\text { surrounding businesses such as } \\
\text { shopping, hotels, and street foods } \\
\text { Space provides access to community }\end{array}$ & 5 & 4.12 & 0.819 & 2.80 & 1.205 \\
\hline & & 31 & $\begin{array}{l}\text { services, utilities and leisure facilities to } \\
\text { minimise the overall cost of living }\end{array}$ & 5 & 3.44 & 1.018 & 4.14 & 0.743 \\
\hline & & 32 & $\begin{array}{l}\text { Space leads to the reduction of health } \\
\text { expenditure for users }\end{array}$ & 5 & 3.48 & 1.229 & 3.99 & 0.929 \\
\hline
\end{tabular}


Table A1. Cont.

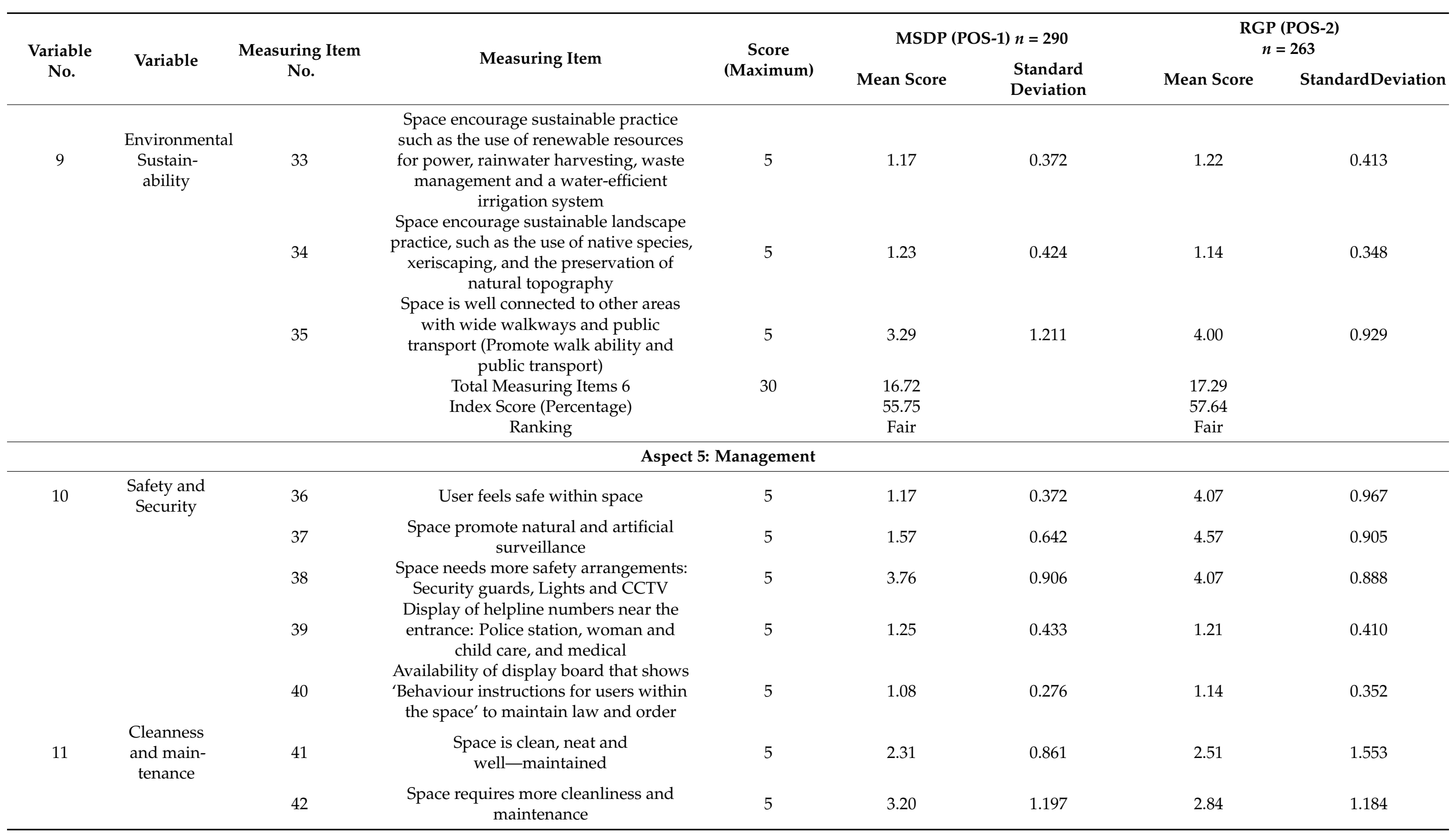


Table A1. Cont.

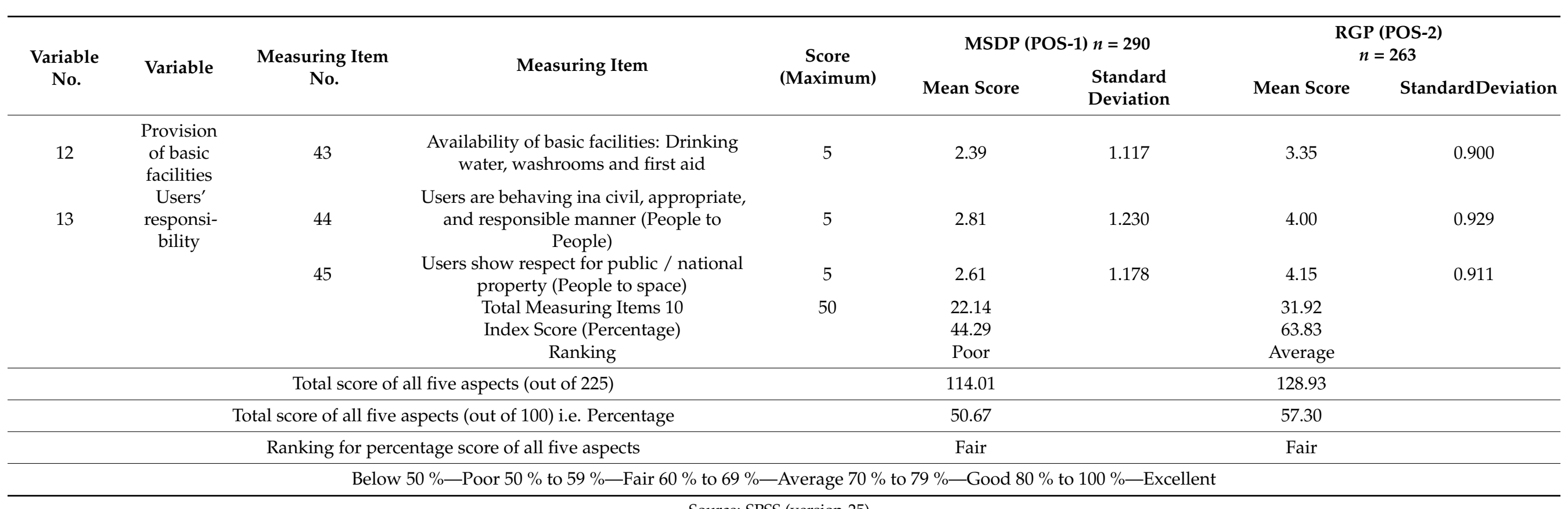


Table A2. Summary of strengths and deficiencies identified by POSI of both POSs.

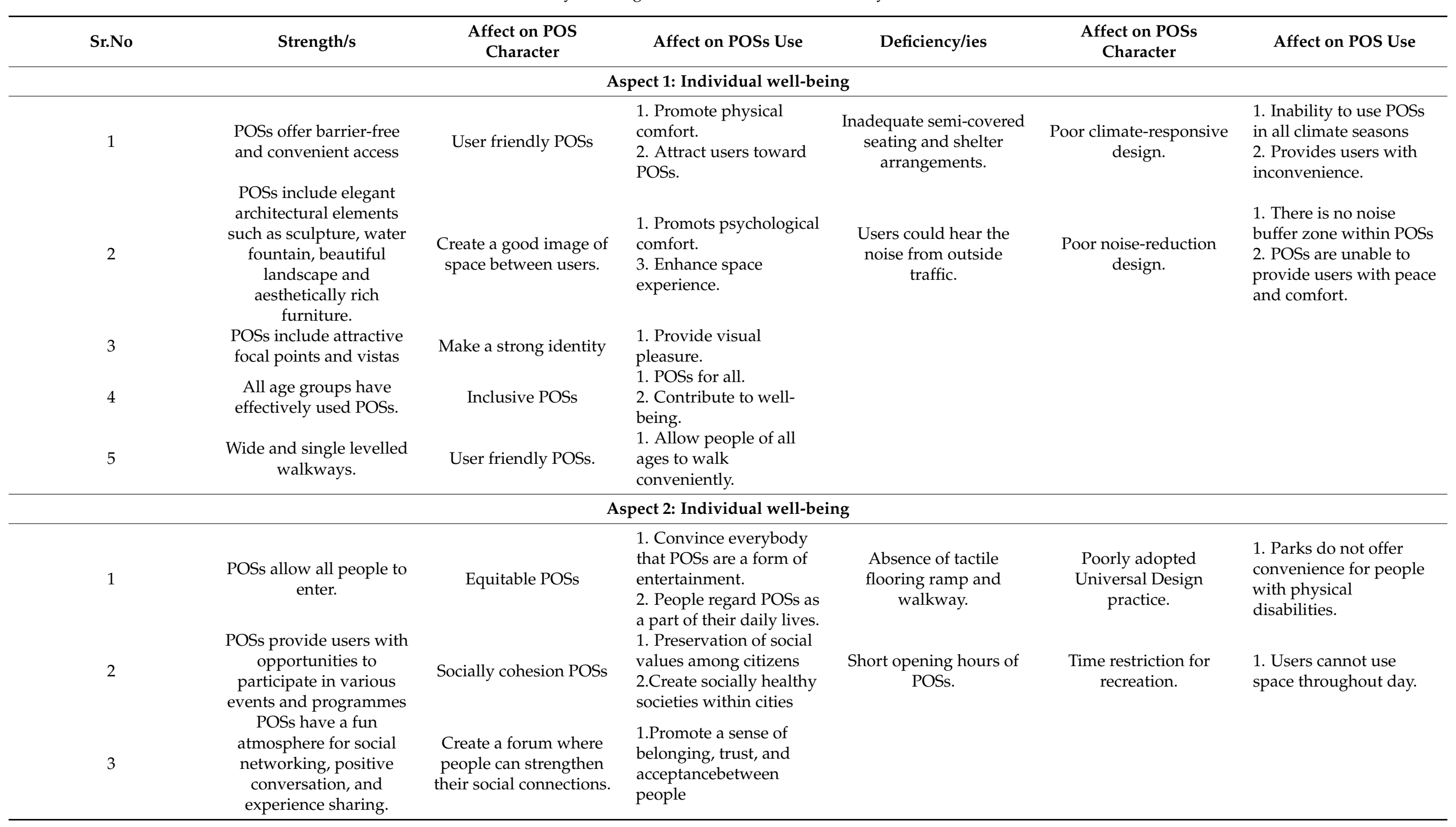


Table A2. Cont.

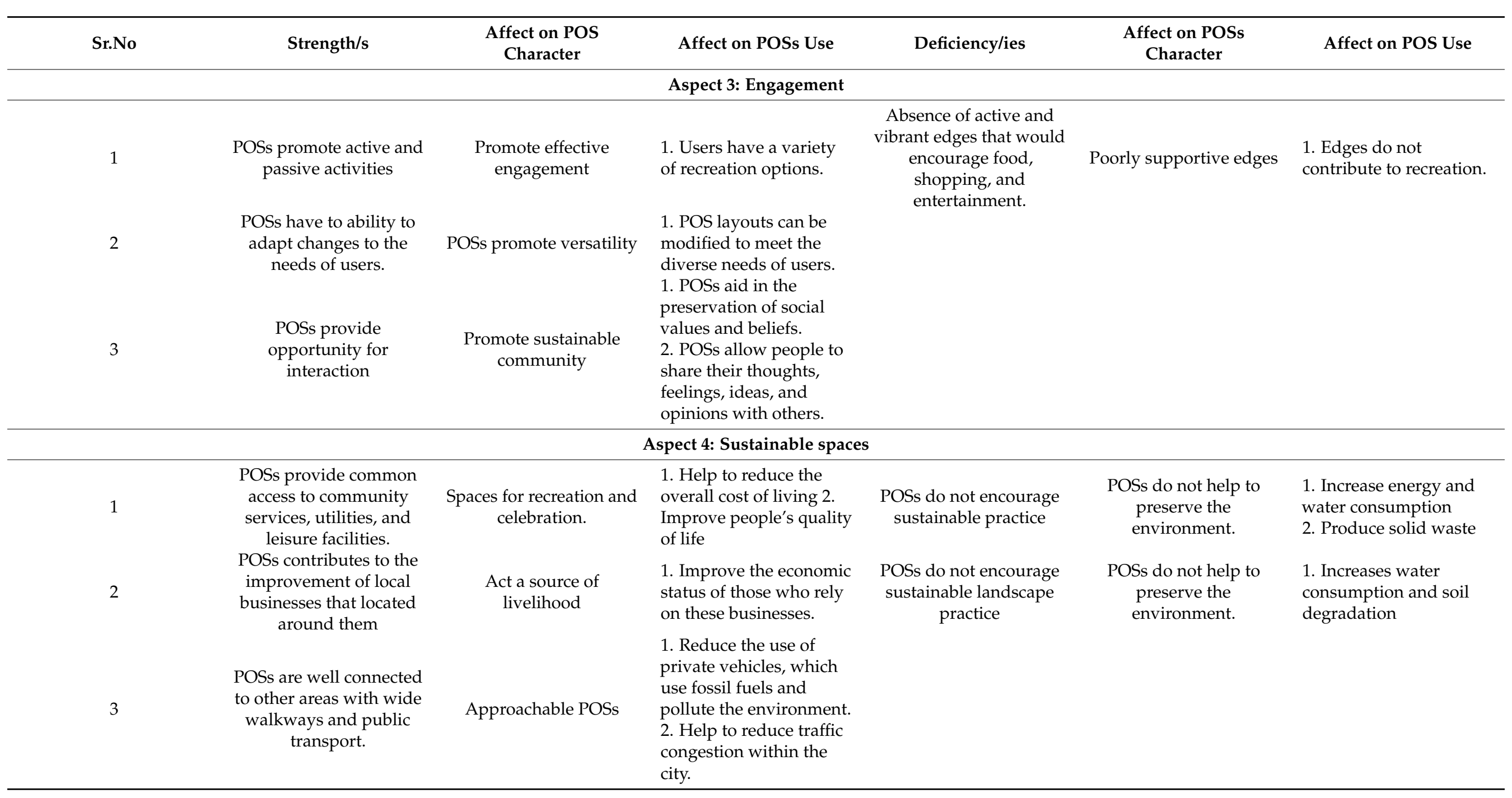


Table A2. Cont.

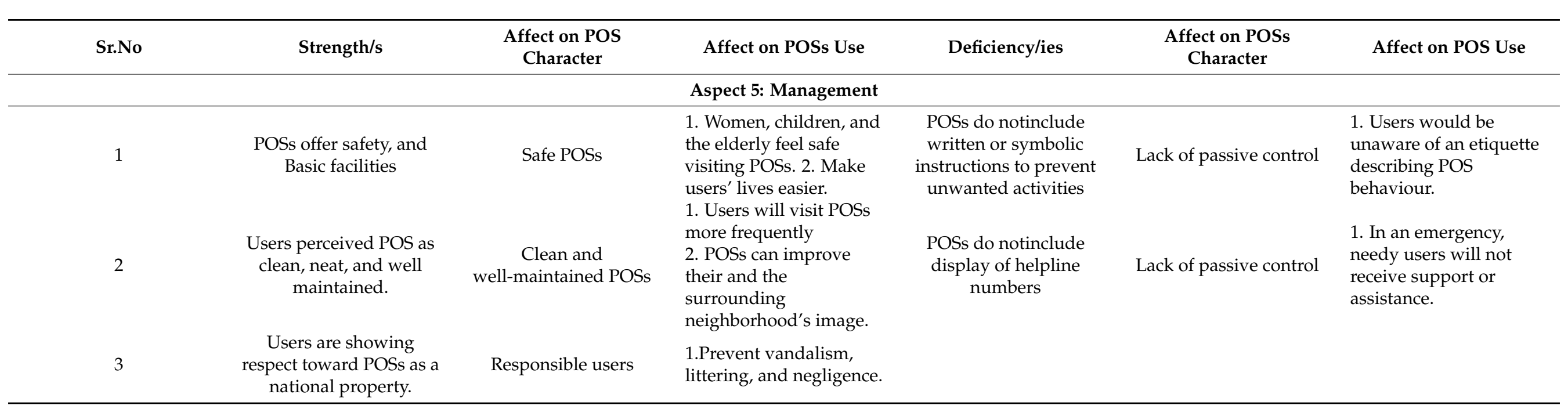




\section{References}

1. Aram, F.; Solgi, E.; Holden, G. The role of green spaces in increasing social interactions in neighbourhoods with periodic markets. Habitat Int. 2019, 84, 24-32. [CrossRef]

2. Marcus, C.C.; Francis, C. (Eds.) People Places: Design Guidlines for Urban Open Space; John Wiley and Sons: Hoboken, NJ, USA, 1997.

3. Chaudhry, P.; Bagra, K.; Singh, B. Urban greenery status of some Indian cities: A short communication. Int. J. Environ. Sci. Dev. 2011, 2, 98. [CrossRef]

4. Amritsar Municipal Corporation. Available online: https://www.amritsarcorp.com/ (accessed on 2 August 2019).

5. Bangalore Municipal Corporation. Available online: http://bbmp.gov.in/home (accessed on 2 August 2019).

6. Chennai Municipal Corporation. Available online: http://www.chennaicorporation.gov.in/ (accessed on 2 August 2019).

7. Nagpur Municipal Corporation. Available online: https://www.nmcnagpur.gov.in/assets/250/2018/10/.../Final_CDP_ Nagpur_-Mar_15.pdf (accessed on 5 August 2019).

8. Mumbai Municipal Corporation. Available online: https://portal.mcgm.gov.in/irj/portal/anonymous (accessed on 6 August 2019).

9. Pune Municipal Corporation. Available online: https:/ /pmc.gov.in/en (accessed on 6 August 2019).

10. URDPFI. Available online: http://mohua.gov.in/link/urdpfi-guidelines.php (accessed on 9 August 2019).

11. World Health Organisation. Available online: www.euro.who.int (accessed on 9 August 2019).

12. Subramanian, D.; Jana, A. Assessing urban recreational open spaces for the elderly: A case of three Indian cities. Urban For. Urban Green. 2018, 35, 115-128. [CrossRef]

13. Sundaram, A.M. Urban green-cover and the environmental performance of Chennai city. Environ. Dev. Sustain. 2011, 13, 107-119. [CrossRef]

14. Budruk, M.; Thomas, H.; Tyrrell, T. Urban green spaces: A study of place attachment and environmental attitudes in India. Soc. Nat. Resour. 2009, 22, 824-839. [CrossRef]

15. Bharath, H.A.; Vinay, S.; Chandan, M.C.; Gouri, B.A.; Ramachandra, T.V. Green to gray: Silicon valley of India. J. Environ. Manag. 2018, 206, 1287-1295. [CrossRef] [PubMed]

16. Nagendra, H.; Nagendran, S.; Paul, S.; Pareeth, S. Graying, greening and fragmentation in the rapidly expanding Indian city of Bangalore. Landsc. Urban Plan. 2012, 105, 400-406. [CrossRef]

17. Rahman, K.M.; Zhang, D. Analyzing the level of accessibility of public urban green spaces to different socially vulnerable groups of people. Sustainability 2018, 10, 3917. [CrossRef]

18. Kuhlman, T.; Farrington, J. What is sustainability? Sustainability 2010, 2, 3436-3448. [CrossRef]

19. Paul, S.; Nagendra, H. Factors influencing perceptions and use of urban nature: Surveys of park visitors in Delhi. Land 2017, 6, 27. [CrossRef]

20. Douglas, O.; Russell, P.; Scott, M. Positive perceptions of green and open space as predictors of neighbourhood quality of life: Implications for urban planning across the city region. J. Environ. Plan. Manag. 2019, 62, 626-646. [CrossRef]

21. Dennis, W. Cultural and Developmental Factors in Perception; Ronald Press: New York, NY, USA, 1951.

22. D'Souza, L.V. Public Perceptions of Urban Community Park Benefits: A Study in Arlington, Texas; Landscape Architecture: London, UK, 2013.

23. Cilliers, E.J.; Timmermans, W.; Van den Goorbergh, F.; Slijkhuis, J.S.A. Designing public spaces through the lively planning integrative perspective. Environ. Dev. Sustain. 2015, 17, 1367-1380. [CrossRef]

24. Carr, S.; Francis, M.; Rivlin, L.G.; Stone, A.M. Public Space; Cambridge University Press: Cambridge, UK, 1992.

25. Woolley, H. Urban Open Spaces; Taylor and Francis: Abingdon, UK, 2003.

26. Parra-Saldívar, A.; Abades, S.; Celis-Diez, J.L.; Gelcich, S. Exploring Perceived Well-Being from Urban Parks: Insights from a Megacity in Latin America. Sustainability 2020, 12, 7586. [CrossRef]

27. Bahriny, F.; Bell, S. Traditional versus Modern? Perceptions and Preferences of Urban Park Users in Iran. Sustainability 2021, 13, 2036. [CrossRef]

28. Whyte, W.H. The Social Life of Small Urban Spaces; The Conservation Foundation: Washington, DC, USA, 1980.

29. Nadarajah, M.; Yamamoto, A. Urban Crisis: Culture and the Sustainability of Cities; Whiley-Bacjwell: Hoboken, NJ, USA, 2006; pp. 1-79.

30. El Din, H.S.; Shalaby, A.; Farouh, H.E.; Elariane, S.A. Principles of urban quality of life for a neighborhood. Hbrc J. 2013, 9, 86-92. [CrossRef]

31. Mitlin, D.; Satterthwaite, D. Sustainable development and cities. Sustain. Environ. Urban. 1996, 4, $23-62$.

32. Goosen, Z.; Cilliers, E.J. Enhancing social sustainability through the planning of third places: A theory-based framework. Soc. Indic. Res. 2020, 150, 835-866. [CrossRef]

33. Manzi, T.; Lucas, K.; Jones, T.L. Social Sustainability in Urban Areas: Communities, Connectivity and the Urban Fabric; Taylor and Francis: Oxfordshire, UK, 2010; pp. 105-159.

34. Back, S. A Study on the Design Checklist for Ecologically Sustainable Public Space. Available online: http://www.kisd.or.kr (accessed on 12 December 2020). 
35. Wiryomartono, B. Urban Design and Urbanism. In Livability and Sustainability of Urbanism; Palgrave Macmillan: Singapore, 2020; pp. 101-123.

36. Macdonald, E. Urban design for sustainable and livable communities: The case of Vancouver. In Transportation, Land Use, and Environmental Planning; Elsevier: Amsterdam, The Netherlands, 2020; pp. 83-104.

37. Nasar, J.L. The evaluative image of the city. J. Am. Plan. Assoc. 1990, 56, 41-53. [CrossRef]

38. Carmona, M.; Heath, T.; Oc, T.; Tiesdell, S. Urban Spaces-Public Places: The Dimensions of Urban Design; Elsevier: Oxford, England, 2003.

39. Shaftoe, H. Convivial Urban Spaces: Creating Effective Public Places; Earthscan: London, UK, 2012.

40. Weijs-Perrée, M.; Dane, G.; van den Berg, P. Analyzing the Relationships between Citizens' Emotions and their Momentary Satisfaction in Urban Public Spaces. Sustainability 2020, 12, 7921. [CrossRef]

41. Mensah, C.A.; Andres, L.; Perera, U.; Roji, A. Enhancing quality of life through the lens of green spaces: A systematic review approach. Int. J. Wellbeing 2016, 6. [CrossRef]

42. Kothencz, G.; Kolcsár, R.; Cabrera-Barona, P.; Szilassi, P. Urban green space perception and its contribution to well-being. Int. J. Environ. Res. Public Health 2017, 14, 766. [CrossRef] [PubMed]

43. Mehta, V. Evaluating public space. J. Urban Des. 2014, 19, 53-88. [CrossRef]

44. PPS. What Makes a Successful Space? 2019. Available online: https://www.pps.org/article/grplacefeat (accessed on 15 September 2019).

45. Peng, Y.; Peng, Z.; Feng, T.; Zhong, C.; Wang, W. Assessing comfort in urban public spaces: A structural equation model involving environmental attitude and perception. Int. J. Environ. Res. Public Health 2021, 18, 1287. [CrossRef] [PubMed]

46. Chen, C.; Luo, W.; Li, H.; Zhang, D.; Kang, N.; Yang, X.; Xia, Y. Impact of perception of green space for health promotion on willingness to use parks and actual use among young urban residents. Int. J. Environ. Res. Public Health 2020, 17, 5560. [CrossRef] [PubMed]

47. Zhou, Z.; Xu, Z. Detecting the pedestrian shed and walking route environment of urban parks with open-source data: A case study in Nanjing, China. Int. J. Environ. Res. Public Health 2020, 17, 4826. [CrossRef]

48. Krishan, A. (Ed.) Climate Responsive Architecture: A Design Handbook for Energy Efficient Buildings; Tata McGraw-Hill Education: Noida, India, 2001.

49. Gautam, A. Climate Responsive Vernacular Architecture: Jharkhand, India. Ph.D. Thesis, Kansas State University, Manhattan, KS, USA, 2008.

50. Wood, L.; Hooper, P.; Foster, S.; Bull, F. Public green spaces and positive mental health-investigating the relationship between access, quantity and types of parks and mental wellbeing. Health Place 2017, 48, 63-71. [CrossRef] [PubMed]

51. Charkhchian, M.; Daneshpour, S.A. Interactions among different dimensions of a responsive public space: Case study in Iran. In Review of Urban and Regional Development Studies: Journal of the Applied Regional Science Conference; Blackwell Publishing Asia: Melbourne, Australia, 2009; Volume 21, pp. 14-36.

52. Jacobs, J. The Death and Life of Great American Cities; Random House: New York, NY, USA, 1961; pp. $321-325$.

53. Lynch, K. The Image of the City; MIT Press: Cambridge, MA, USA, 1960; Volume 11.

54. Holland, C.; Clark, A.; Katz, J.; Peace, S. Social Interactions in Urban Public Places; Policy Press: Bristol, UK, 2007.

55. Moulay, A.; Ujang, N.; Said, I. Legibility of neighborhood parks as a predicator for enhanced social interaction towards social sustainability. Cities 2017, 61, 58-64. [CrossRef]

56. Wolfgang, F.P.; Ostroff, E. Universal Design Handbook; Nova: New York, NY, USA, 2001.

57. Jennings, V.; Bamkole, O. The relationship between social cohesion and urban green space: An avenue for health promotion. Int. J. Environ. Res. Public Health 2019, 16, 452. [CrossRef]

58. Enssle, F.; Kabisch, N. Urban green spaces for the social interaction, health and well-being of older people-An integrated view of urban ecosystem services and socio-environmental justice. Environ. Sci. Policy 2020, 109, 36-44. [CrossRef]

59. Zamanifard, H.; Alizadeh, T.; Bosman, C.; Coiacetto, E. Measuring experiential qualities of urban public spaces: Users' perspective. J. Urban Des. 2019, 24, 340-364. [CrossRef]

60. Francis, M. Urban Open Space: Designing for User Needs; Island Press: Washington, DC, USA, 2003.

61. Ujang, N. Place attachment and continuity of urban place identity. Procedia Soc. Behav. Sci. 2012, 49, 156-167. [CrossRef]

62. Gehl, J. Life between Buildings: Using Public Space; Island Press: Washington, DC, USA, 2011.

63. Askari, A.H.; Soltani, S.; Mohd, I. Engagement in public open spaces across age groups: The case of Merdeka Square in Kuala Lumpur city, Malaysia. Urban Des. Int. 2015, 20, 93-106. [CrossRef]

64. Eizenberg, E.; Jabareen, Y. Social sustainability: A new conceptual framework. Sustainability 2017, 9, 68. [CrossRef]

65. UN World Commission on Environment and Development. Our Common Future; Oxford University Press: Oxford, UK, 1987.

66. Sugiyama, T.; Carver, A.; Koohsari, M.J.; Veitch, J. Advantages of public green spaces in enhancing population health. Landsc. Urban Plan. 2018, 178, 12-17. [CrossRef]

67. Financial Times. Definition of Environmental Sustainability. 2018. Available online: http://lexicon.ft.com/Term?term= environmental-sustainability (accessed on 6 August 2019).

68. Blowers, A. (Ed.) Planning for a Sustainable Environment; Routledge: London, UK, 2013.

69. Selman, P. What do we mean by sustainable landscape? Sustain. Sci. Pract. Policy 2008, 4, 23-28. 
70. VanDerZanden, A.M.; Cook, T.W. Sustainable Landscape Management: Design, Construction, and Maintenance; John Wiley and Sons: Hoboken, NJ, USA, 2010.

71. Williams, T.G.; Logan, T.M.; Zuo, C.T.; Liberman, K.D.; Guikema, S.D. Parks and safety: A comparative study of green space access and inequity in five US cities. Landsc. Urban Plan. 2020, 201, 103841. [CrossRef]

72. Oc, T.; Tiesdell, S. Safer City Centres: Reviving the Public Realm; Paul Chapman Publishing: London, UK, 1997.

73. Lang, J.; Marshall, N. Urban Squares as Places, Links and Displays: Successes and Failures; Routledge: London, UK, 2016.

74. Carmona, M. Principles for public space design, planning to do better. Urban Des. Int. 2019, 24, 47-59. [CrossRef]

75. Lahoti, S.; Kefi, M.; Lahoti, A.; Saito, O. Mapping methodology of public urban green spaces using GIS: An example of Nagpur City, India. Sustainability 2019, 11, 2166. [CrossRef]

76. Tashakkori, A.; Teddlie, C. (Eds.) Sage Handbook of Mixed Methods in Social \& Behavioral Research; Sage: New York, NY, USA, 2010.

77. Creswell, J.W.; Clark, V.L.P. Designing and Conducting Mixed Methods Research; Sage publications: Thousand Oaks, CA, USA, 2017.

78. Kothari, C.R. Research Methodology: Methods and Techniques; New Age International: Mumbai, India, 2004.

79. Fink, A. The Survey Handbook; Sage: Thousand Oaks, CA, USA, 2003.

80. Barlett, J.E.; Kotrlik, J.W.; Higgins, C.C. Organizational research: Determining appropriate sample size in survey research. Inf. Technol. Learn. Perform. J. 2001, 19, 43.

81. Hazelrigg, L. Inference. In The Handbook of Data Analysis; Hardy, M., Bryman, A., Eds.; Sage: London, UK, 2009.

82. Sreetheran, M. Exploring the urban park use, preference and behaviours among the residents of Kuala Lumpur, Malaysia. Urban For. Urban Green. 2017, 25, 85-93. [CrossRef]

83. Gaikwad, A.; Shinde, K. Use of parks by older persons and perceived health benefits: A developing country context. Cities 2019, 84, 134-142. [CrossRef]

84. Ryan, R.L. Exploring the effects of environmental experience on attachment to urban natural areas. Environ. Behav. 2005, 37, 3-42. [CrossRef] 